\title{
ANALISIS KUALITAS PELAYANAN TERHADAP KEPUASAN PASIEN RAWAT JALAN DI PUSKESMAS PUUWATU KOTA KENDARI MENGGUNAKAN METODE SERVQUAL
}

\section{Analysis Of Quality Service Towards Out-Patient Satisfaction At Puskesmas Puuwatu Kendari City}

\author{
Adryan Fristiohady 1,2* \\ La Ode Muhammad \\ Fitrawan ${ }^{1,2}$ \\ Yusniati Dwi Pemudi \\ Sunandar Ihsan' \\ Ruslin I \\ Mentarry Bafadal \\ Nurwati3 \\ Ruslan4
}

*IFakultas Farmasi, Universitas Halu Oleo, Kendari, Sulawesi Tenggara, Indonesia

2Pengurus Cabang Ikatan Apoteker Indonesia Kota Kendari, Kendari, Sulawesi Tenggara, Indonesia

${ }^{3}$ Fakultas Ekonomi dan Bisnis, Universitas Halu Oleo, Kendari, Sulawesi Tenggara, Indonesia

3Fakultas Matematika dan IImu Pengetahuan Alam, Universitas Halu Oleo, Kendari, Sulawesi Tenggara, Indonesia

*email:

adryanfristiohady@uho.ac.id

Kata Kunci:

Kepuasan Pasien

Kualitas Pelayanan

Gap

\section{Keywords:}

Patient Satisfaction

Service Quality

Gap

\begin{abstract}
Abstrak
Kualitas pelayanan rawat jalan dapat diukur dengam model SERVQUAL yang memperhatikan 5 dimensi yaitu I) bukti langsung, 2) keandalan, 3) daya tanggap, 4) jaminan, dan 5) empati. Tujuan dari penelitian ini untuk melihat pengaruh kualitas pelayanan terhadap kepuasan pasien rawat jalan pada Puskesmas Puuwatu Kota Kendari. Subjek pada penelitian ini adalah pasien rawat jalan sebanyak 34 orang. Teknik analis yang digunakan adalah analisis gap untuk membandingkan harapan dan kenyataan yang diterima pasien, uji normalitas data berdasarkan koesioner kepuasan pasien yang telah diuji validasi.Hasil penelitian ini ini menunjukkan nilai rata-rata gap di apotek Puskesmas Puuwatu Kota Kendari sebesar 0,27. Dari nilai gap tersebut, pada apotek puskesmas Puuwatu nilai gap terendah yaitu tempat pelayanan dan pemberian informasi obat tidak memadai sebesar -0,24. Berdasarkan uji $t$ berpasangan dimana nilai signifikan > 0,05 maka $\mathrm{Ho}$ ditolak dan $\mathrm{H}_{\mathrm{a}}$ diterima sehingga artinya terdapat pengaruh yang signifikan antara kualitas pelayanan terhadap kepuasan pasien di Puskesmas Puuwatu Kota Kendari.Kesimpulan dari penelitian ini adalah terjadi kesenjangan antara harapan dan kenyataan yang signifikan pada Puskesmas Puuwatu Kota Kendari.
\end{abstract}

\begin{abstract}
The quality of outpatient services can be measured by the SERVQUAL model that takes into account 5 dimensions, namely I) tangible, 2) reliability, 3) responsiveness, 4) assurance, and 5) empathy. The purpose of this study was to look at the effect of service quality on outpatient satisfaction at the Apotek Puskesmas Puuwatu Kota Kendari. The subjects in this study were 34 outpatients. The analysis technique used is gap analysis to compare expectations and reality received by patients, normality test data based on questionnaire patient satisfaction that has been tested for validation.The results of this study indicate the average value of the gap in the pharmacy of Apotek Puskesmas Puuwatu Kota Kendari amounting to 0,27 . From the value of the gap, the lowest gap value in the pharmacy center of Puuwatu is the place of service and the provision of inadequate drug information of -0.24 . Based on the paired t-test where significant value $>0.05$ then $\mathrm{Ho}$ is rejected and $\mathrm{Ha}$ accepted so that means a significant difference between the quality of service to the satisfaction of patients in Apotek Puskesmas Puuwatu Kota Kendari. The conclusion of this study is that there is a significant gap between expectations and reality at the Apotek Puskesmas Puuwatu Kota Kendari.
\end{abstract}




\section{PENDAHULUAN}

Masalah kesehatan menjadi hal yang sangat utama saat ini. Peningkatan taraf hidup masyarakat, disertai dengan meningkatnya pula tuntutan masyarakat akan kualitas kesehatan yang diharapkan. Salah satu penyedia jasa pelayanan kesehatan seperti puskesmas dituntut untuk meningkatkan mutu pelayanan yang lebih baik, tidak hanya pelayanan yang bersifat penyembuhan penyakit tetapi juga meliputi pelayanan yang bersifat pencegahan (preventif) untuk meningkatkan mutu hidup serta memberikan kepuasan bagi konsumen selaku pengguna jasa kesehatan.

Pelayanan kesehatan adalah setiap upaya yang diselenggarakan sendiri atau secara bersama-sama dalam suatu organisasi untuk memelihara dan meningkatkan kesejahteraan, mencegah dan menyembuhkan penyakit serta memulihkan kesehatan perseorangan, keluarga, kelompok ataupun masyarakat [I].

Puskesmas yaitu suatu kesatuan organisasi kesehatan fungsional yang merupakan pusat kesehatan masyarakat yang juga membangun peran serta masyarakat disamping memberikan pelayanan secara menyeluruh dan terpadu kepada masyarakat diwilayah kerjanya [2].

Standar pelayanan kefarmasian yaitu kriteria yang dipergunakan sebagai panduan bagi tenaga kefarmasian dalam melaksanakan pelayanan kefarmasian. Pelayanan kefarmasian di Puskesmas harus mendukung tiga fungsi utama pususkesmas, yaitu sebagai pusat pendorong pembangunan berwawasan kesehatan, pusat pemberdayaan masyarakat dan pusat pelayanan kesehatan tingkat pertama yang meliputi pelayanan kesehatan individu dan pelayanan kesehatan masyarakat. Pelayanan Kefarmasian merupakan kegiatan yang terpadu dengan tujuan untuk mengidentifikasi, mencegah dan menuntaskankan masalah obat dan masalah yang berkaitan dengan kesehatan [3].

Penurunan jumlah kunjungan masyarakat ke puskesmas dapat disebabkan oleh ketidakpuasan masyarakat terhadap pelayanan puskesmas. Adanya ketidakpuasan ini menunjukkan bahwa pelayanan yang diberikan puskesmas belum mampu memenuhi harapan masyarakat. [4].

Persaingan yang semakin ketat akhir-akhir ini menuntut sebuah lembaga penyedia jasa/layanan untuk selalu memanjakan konsumen atau pelanggan dengan memberikan pelayanan terbaik. Para pelanggan akan mencari produk berupa barang atau jasa dari perusahaan yang dapat memberikan pelayanan yang terbaik kepadanya. Kualitas pelayanan merupakan komponen penting dalam persepsi konsumen, juga sangat penting dalam pengaruhnya terhadap kepuasan konsumen. Semakin baik kualitas maka jasa yang diberikan maka akan semakin baik pula citra jasa tersebut dimata konsumen [5]

Kata kepuasan (satisfaction) berasal dari bahasa Latin “satis" (artinya cukup baik, memadai atau layak) dan "facio" (membuat). Kepuasan bisa diartikan sebagai "upaya pemenuhan sesuatu" atau "membuat sesuatu memadai" [6]. Kepuasan pelanggan didasarkan pada terpenuhi atau terlampauinya harapan pelanggan. Loyalitas pelanggan dan profitabilitas perusahaan yang maksimal dalam jangka panjang diperoleh melalui kepuasan pelanggan. Puskesmas dalam upayanya meningkatkan pelayanan dan meningkatkan kepuasan pasien perlu mengadakan sistem pengukuran kepuasan pelanggan untuk dapat mengetahui kebutuhan dan harapan pasien mengingat bahwa harapan merupakan standar pembanding untuk menilai kualitas pelayanan di fasilitas kesehatan [7].

Kepuasan konsumen dapat mempengaruhi minat untuk kembali ke puskesmas yang sama. Konsumen yang puas akan menjadi pelanggan yang loyal, berupa promosi dari mulut ke mulut bagi calon konsumen lainnya, yang diharapkan sangat positif bagi puskesmas. [8].

Pada umumnya pasien yang merasa tidak puas akan mengajukan aduan pada pihak puskesmas. Aduan yang tidak segera ditangani akan mengakibatkan menurunnya kepuasan pasien terhadap kapabilitas pelayanan 
kesehatan di puskemas tersebut. Kepuasan konsumen telah menjadi konsep sentral dalam wacana bisnis dan manajemen. Konsumen umumnya mengharapkan produk berupa barang atau jasa yang dikonsumsi dapat diterima dan dinikmatinya dengan pelayanan yang memuaskan [9].

Puskesmas Puuwatu merupakan sarana kesehatan vital di Kecamatan Puuwatu, Kota Kendari, memiliki pelayanan rawat inap dan rawat jalan. Puskesmas ini diharpkan dapat menjadi sarana pelayanan kesehatan dasar bagi masyarakat karena keberadaan Puskesmas lebih dekat dengan masyarakat daripada Rumah Sakit. Dimana keberadaan Rumah sakit ditingkat kecamatan relatif sedikit, sebagian besar ditingkat kabupaten atau propinsi saja. Disamping itu biaya periksa, biaya obat relatif lebih murah dan prosedurnya lebih mudah di Puskesmas daripada di Rumah Sakit. Dikarenakan pentingnya keberadaan Puskesmas di sekitar masyarakat, maka Puskesmas harus berusaha melayani masyarakat menurut standar pelayanan setingkat Puskesmas dengan sebaik mungkin.

Dilakukan penelitian ini di Apotek Puskesmas Puuwatu Kota Kendari karena masih banyak keluhan dari pasien mengenai kualitas pelayanan yang diberikan oleh puskesmas seperti sarana ruang tunggu yang dianggap oleh pasien kurang memadai karena pasien yang datang mengunjungi terlalu ramai dan penyediaan sarana kurang tunggu masih sedikit tetapi . Konsep pengukuran kesenjangan antara ekspektasi dan persepsi terhadap nilai gap Servqual terbukti sangat berguna untuk menilai tingkat kualitas pelayanan selain itu metode servqual lebih aplikabel dan mudah untuk dilakukan. SERVQUAL merupakan pengukuran kepuasan pelanggan yang terletak pada lima dimensi kualitas pelayanan yaitu kehandalan (reliability), jaminan (assurance), bukti fisik (tangible), empati (empathy), dan daya tanggap (responsiveness). Lanjutan dari servqual yang berguna sebagai pedoman dalam mengalokasikan sumber-daya organisasi terbatas pada bidang-bidang spesifik yaitu Indeks Performance Analysis, dimana perbaikan kinerjanya berdampak positif besar pada kepuasan pelanggansehingga memberikan suatu masukan yang berharga bagi pembuat kebijakan dalam merancang strategi yang tepat [10].

\section{METODOLOGI}

Dalam penelitian ini, masalah yang diidentifikasi adalah tentang Pengaruh Kualitas Pelayanan Terhadap Kepuasan Pasien di Puskesmas Puuwatu Kota Kendari. Penelitian ini menggunakan metode kuantitatif. Penelitian ini dilaksanakan di Puskesmas Puuwatu Kota Kendari dengan subjek penelitian yaitu pasien Rawat Jalan. Waktu penelitian dilaksanakan selama 3 bulan. Populasi yang diambil oleh peneliti yaitu Semua pasien Puskesmas Puuwatu Kota Kendari selama tiga bulan yakni pada bulan November, Desember 2019 dan Januari 2020. Adapun jumlah populasi tersebut sebanyak I300 pasien. Dikarenakan jumlah populasi yang relatif besar, Pengambilan sampel kepada pasien sebanyak 33 pasien dilakukan secara Consecutive Sampling, yaitu pengambilan sampel secara acak yang memenuhi syarat inklusi sampai kurun waktu yang ditentukan. Sehingga jumlah sampel yang diperlukan terpenuhi [I I].

Teknik pengumpulan data dengan cara menyebarkan kuesioner atau pertanyaan secara tertulis kepada responden untuk memberikan pendapatnya. Atas pernyataan dari indikator-indikator pengukuran variabel yang diteliti. Instrumen disusun sesuai variabel yang diteliti yang dilengkapi dengan petunjuk cara pengisiannya secara jelas serta sudah memenuhi uji validitas dan reliabilitas. Kemudian data diolah dengan menggunakan teknik analisis data dalam penelitian ini yaitu:

a. Analisis Gap

Tingkat kepuasan pasien dijelaskan dengan menggunakan analisis kesenjangan (gap). Analisis ini membandingkan mean antara harapan dengan kenyataan yang diterima pasien dari dimensi 
Adryan Fristiohady, La Ode Muhammad Fitrawan, Yusniati Dwi Pemudi, Sunandar Ihsan, Mentarry Bafadal, Nurwati, Ruslan. 2020.

Analysis Of Quality Service Towards Out-Patient Satisfaction At Puskesmas Puuwatu Kendari City

pelayanan yaitu reliability, responsiveness, assurance, empathy, dan tangibles.

b. Uji normalitas data

Uji yang digunakan untuk mengetahui apakah data terdistribusi normal atau tidak yaitu dengan menggunakan Kolmogorov-Smirnov untuk sampel besar (lebih dari 50 responden) atau Shapiro-Wilk untuk sampel kecil (kurang dari 50 responden). Apabila nilai signifikansi $>0,05$ maka data berdistribusi normal (data parametrik) dan dapat dianalisis dengan paired t-test. Sedangkan apabila nilai signifikansi $<0,05$ maka data berdistribusi tidak normal (data non-parametrik) dan dapat dianalisis menggunakan uji Wilcoxon.

c. Uji Paired T-Test

Uji ini dilakukan untuk mengetahui apakah terdapat perbedaan yang bermakna atau tidak dari kenyataan dan harapan yang diteliti sehingga dapat ditentukan apakah Ho ditolak atau diterima. Apabila hasil yang didapatkan terjadi perbedaan yang signifikan maka Ho ditolak tetapi apabila perbedaan yang terjadi tidak signifikan maka Ho diterima. 'Uji paired t-test dilakukan jika dua data yang dibandingkan terdistribusi normal atau uji Wilcoxon jika minimal dari salah satu data yang dibandingkan tidak terdistribusi normal yang dilihat dari nilai kenyataan dan harapan.

\section{HASIL DAN PEMBAHASAN}

\section{A. Gambaran Umum Puskesmas Puuwatu}

Puskesmas Puuwatu berlokasi di jalan Prof. Muh. Yamin No. 64 Kelurahan Puuwatu, Kecamatan Puuwatu, Kota Kendari, Provinsi Sulawesi Tenggara. Luas wilayah kerja Puskesmas Puuwantu yaitu 2I,56 km². Wilayah kerja Puskesmas Puuwantu meliputi 6 kelurahan diantaranya: Kelurahan Puuwatu, Kelurahan Watulondo, Kelurahan Tobuuha, Kelurahan Punggolaka, Kelurahan Lalodati, Kelurahan Abeli Dalam (Puskesmas Puuwantu, 2017).

\section{B. Analisis Gap}

Tabel I. Analisis Gap pada Puskesmas Puuwatu

\begin{tabular}{|c|c|c|c|c|}
\hline Dimensi & Pertanyaan & Kenyataan & Harapan & $\begin{array}{c}\Sigma \\
\mathrm{GAP}\end{array}$ \\
\hline \multirow{9}{*}{ Tangible } & $\begin{array}{l}\text { Kerapian dan } \\
\text { kebersihan }\end{array}$ & 3,94 & 4,15 & -0.21 \\
\hline & $\begin{array}{l}\text { ruang tunggu } \\
\text { Terdapat } \\
\text { fasilitas seperti }\end{array}$ & & & \\
\hline & $\begin{array}{ll}\text { AC, TV } & \text { atau } \\
\text { Majalah } & \text { yang } \\
\text { nyaman } & \end{array}$ & 3,91 & 3,94 & -0.03 \\
\hline & $\begin{array}{l}\text { Tempat } \\
\text { penyerahan }\end{array}$ & 4.21 & 4.00 & 0.21 \\
\hline & $\begin{array}{l}\text { obat yang } \\
\text { memadai }\end{array}$ & 4.21 & 4,00 & 0.21 \\
\hline & $\begin{array}{l}\text { Tempat } \\
\text { pelayanan dan }\end{array}$ & & & \\
\hline & $\begin{array}{l}\text { pemberian } \\
\text { informasi obat } \\
\text { yang memadai }\end{array}$ & 3,88 & 4,12 & -0.24 \\
\hline & $\begin{array}{l}\text { Kerapian } \\
\text { penampilan } \\
\text { petugas apotek }\end{array}$ & 3,94 & 3,88 & 0.06 \\
\hline & Rata-rata & 3,97 & 4,01 & -0.04 \\
\hline \multirow{5}{*}{ Reliability } & $\begin{array}{l}\text { Pelayanan resep } \\
\text { mudah dan tidak } \\
\text { berbelit-belit }\end{array}$ & 4,00 & 4,06 & -0.06 \\
\hline & $\begin{array}{l}\text { Obat yang } \\
\text { diresepkan } \\
\text { selalu tersedia } \\
\text { dalam apotek } \\
\text { Penyerahan }\end{array}$ & 4,02 & 3,76 & 0.26 \\
\hline & $\begin{array}{l}\text { obat selalu } \\
\text { sesuai nomor } \\
\text { antrian resep }\end{array}$ & 3,88 & 4,00 & -0.12 \\
\hline & $\begin{array}{l}\text { Mutu kemasan } \\
\text { obat yang } \\
\text { diterima dalam } \\
\text { keadaan baik }\end{array}$ & 3,82 & 3,73 & 0.09 \\
\hline & Rata-rata & 3,93 & 3,88 & 0.05 \\
\hline \multirow{8}{*}{ Responsiveness } & $\begin{array}{l}\text { Petugas apotek } \\
\text { segera } \\
\text { menyiapkan }\end{array}$ & 3,91 & 4,00 & -0.09 \\
\hline & $\begin{array}{l}\text { obat ketika } \\
\text { menerima resep }\end{array}$ & & $T, 00$ & -0.07 \\
\hline & $\begin{array}{l}\text { Petugas apotek } \\
\text { tanggap masalah } \\
\text { pasien }\end{array}$ & 3,94 & 3,73 & 0.21 \\
\hline & $\begin{array}{l}\text { Petugas apotek } \\
\text { penyerahan }\end{array}$ & & & \\
\hline & $\begin{array}{l}\text { obat segera } \\
\text { memberikan }\end{array}$ & & & \\
\hline & $\begin{array}{l}\text { informasi cara } \\
\text { pakai, dosis } \\
\text { pemakaian, efek } \\
\text { samping obat }\end{array}$ & 3.97 & 4,09 & -0.12 \\
\hline & $\begin{array}{l}\text { Petugas apotek } \\
\text { tidak bingung } \\
\text { hadapi pasien }\end{array}$ & 4,18 & 4,18 & 0 \\
\hline & Rata-rata & 4 & 4 & 0 \\
\hline \multirow{7}{*}{ Assurance } & $\begin{array}{l}\text { Penampilan dan } \\
\text { pengetahuan } \\
\text { petugas apotek } \\
\text { menyakinkan }\end{array}$ & 4,21 & 4,09 & 0.12 \\
\hline & $\begin{array}{l}\text { Petugas apotek } \\
\text { menyiapkan } \\
\text { obat benar dan } \\
\text { teliti }\end{array}$ & 4,03 & 3,76 & 0.27 \\
\hline & $\begin{array}{l}\text { Petugas apotek } \\
\text { kembali } \\
\text { mencocokkan }\end{array}$ & & & \\
\hline & $\begin{array}{l}\text { nomor resep } \\
\text { dan nama pasien } \\
\text { saat } \\
\text { menyerahkan } \\
\text { obat }\end{array}$ & 4,30 & 3,97 & 0.33 \\
\hline & $\begin{array}{l}\text { Obat yang } \\
\text { diserahkan }\end{array}$ & & & \\
\hline & $\begin{array}{l}\text { kepada pasien } \\
\text { dalam kondisi } \\
\text { baik }\end{array}$ & 4,21 & 4,09 & 0.12 \\
\hline & Rata-rata & 4,18 & 3,97 & 0.21 \\
\hline
\end{tabular}




\begin{tabular}{|c|c|c|c|c|}
\hline & $\begin{array}{l}\text { Petugas apotek } \\
\text { memberikan } \\
\text { pelayanan } \\
\text { dengan sopan } \\
\text { dan ramah }\end{array}$ & 3,97 & 3,97 & 0 \\
\hline & $\begin{array}{l}\text { Petugas apotek } \\
\text { lendengarkan } \\
\text { eluhan dan } \\
\text { ertanyaan pasien } \\
\text { engan sabar }\end{array}$ & 4,15 & 3,97 & 0.18 \\
\hline \multirow[t]{6}{*}{ Emphaty } & $\begin{array}{l}\text { Petugas apotek } \\
\text { memberikan } \\
\text { perhatian } \\
\text { kepada pasien }\end{array}$ & 4,06 & 3,91 & 0.15 \\
\hline & $\begin{array}{l}\text { Petugas apotek } \\
\text { memberikan }\end{array}$ & & & \\
\hline & $\begin{array}{lr}\text { pelayanan } & \text { yang } \\
\text { sama } & \text { tanpa }\end{array}$ & 4,15 & 3,73 & 0.42 \\
\hline & $\begin{array}{l}\text { membedakan } \\
\text { pasien }\end{array}$ & & & \\
\hline & $\begin{array}{ll}\text { Keberadaan } & \\
\text { apoteker } & \mathrm{di} \\
\text { apotek } & \\
\text { puskesmas } & \end{array}$ & 4,00 & 3,68 & 0.32 \\
\hline & Rata-rata & 4,06 & 3,85 & 0.21 \\
\hline
\end{tabular}

Kualitas pelayanan dalam penelitian ini menggunakan indikator kepuasan pasien yaitu apa yang dirasakan atas pelayanan yang diterima dari puskesmas dengan membandingkan dengan apa yang diharapankannya. Pendekatan yang digunakan menggunakan service quality (servqual) yang dikembangkan oleh Parasuraman, et al (2004) yang terdiri dari lima dimensi kualitas yaitu tangible, reliability, assurance, ressponsiveness dan empathy.

Analisis tiap dimensi berdasarkan urutan dari gap terbesar ke gap terkecil dapat dijabarkan sebagai berikut:

I) Tangible

Tangible merupakan tanggapan pasien terhadap bukti fisik yang disediakan oleh apotek puskesmas. Pada tabel 4.3 nilai gap yang paling kecil yaitu mengenai tempat pelayan dan pemberian informasi obat yang memadai yaitu -0,2I dan yang paling besar mengenai tempat penyerahan obat yang memadai yaitu 0,2I. Hal ini berarti pasien kurang puas dengan layanan yang diberikan dan pada butir ke 3 dan ke 5 pasien cukup.

2) Reliability

Reliability menunjukkan kemampuan apotek untuk melaksanakan pelayanan yang dapat diandalkan dan terpercaya. Pada tabel 4.3 nilai gap yang paling kecil mengenai penyerahan obat sesuai nomor antrian yaitu -0,12 dan yang paling besar mengenai obat yang diresepkan selalu tersedia diapotek yaitu 0,21 . Hal ini berarti pasien kurang puas dengan layanan yang diberikan dan pada butir ke 2 dan ke 4 pasien cukup puas dengan layanan yang diberikan dari dimensi Reliability.

3) Responsiveness

Responsiveness merupakan tanggapan pasien terhadap kesediaan para petugas apotek membantu pasien dan memberikan pelayanan secara tanggap. Pada tabel 4.3 nilai gap yang paling kecil mengenai petugas apotek saat menyerahkan obat segera menjelaskan informasi obat kepada pasien yaitu $-0,12$ dan yang paling besar mengenai petuga apotek tanggap masalah pasien yaitu 0,2I. $\mathrm{Hal}$ ini berarti pasien kurang puas dengan layanan yang diberikan dan pada butir ke 2 dan 4 pasien cukup puas dengan layanan yang diberikan dari dimensi Responsiveness.

4) Assurance

Assurance merupakan tanggapan pasien terhadap pengetahuan dan kesopanan petugas apotek sehingga dapat merasa yakin dan percaya pada saat membeli obat. Pada tabel 4.3 nilai gap yang paling kecil mengenai penampilan dan pengetaahuan petugas apotek meyakinkan yaitu 0,12 dan yang paling besar mengenai petugas apotek kembali mencocokkan nomor resep dan nama pasien saat menyerahkan obat yaitu 0 . Hal ini berarti pasien cukup puas dengan layanan yang diberikan dari dimensi Assurance.

\section{5) Emphaty}

Emphaty merupakan tanggapan pasien terhadap perhatian secara personal yang diberikan petugas apotek. Pada tabel 4.2 nilai gap yang paling kecil mengenai petugas apotek memberikan pelayanan yang sopan dan ramah yaitu 0 dan yang paling besar mengenai petugas apotek memberikan pelayanan yang sama tanpa membedakan siapa-siapa yaitu 
0,42. Hal ini berarti pasien cukup puas dengan layanan yang diberikan dari dimensi Emphaty.

\section{Diagram Kartesius pada Puskesmas Puuwatu}

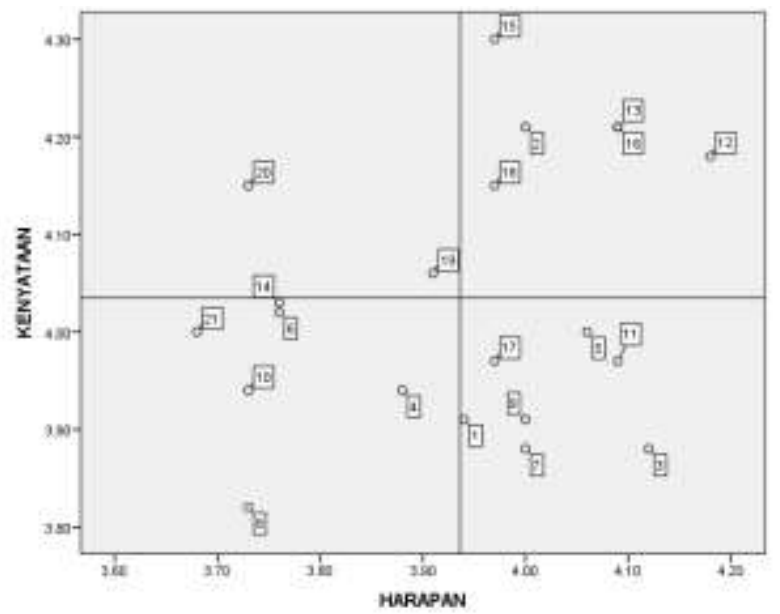

Gambar I. Diagram Kartesius Pada Puskesmas Puuwatu

I. Kuadran I

Pada posisi ini, jika dilihat dari kepentingan pasien, pelayanan berada pada tingkat tinggi, tetapi jika dilihat dari kenyataannya, pasien merasakan tingkat yang rendah, sehingga menuntut adanya perbaikan. Adapaun item-item termasuk dalam kuadran ini adalah petugas apotek mendengarkan keluhan dan pertanyaan pasien; petugas apotek memberikan perhatian kepada pasien dan keluarganya dianggap penting oleh pasien karena kenyataan yang diterima oleh pasien tidak sesuai apa yang mereka harapkan sehingga masih mengecewakan pasien.

2. Kuadran II

Kuadran ini ditunjukkan perihal yang perlu dipertahankan karena tingkat pelaksanaan dari faktor pelayana telah sesuai antara harapan dan kenyataan serta mampu menarik pasien untuk memanfaatkannya, yaitu kenyamanan ruang tunggu; petugas apotek menyerahkan obat segera memberikan informasi obat; penampilan dan pengetahuan petugas apotek meyakinkan; petugas apotek menyiapkan obat benar dan teliti; obaat yang diserahkan kepada pasien dalam kondisi baik.
Sehingga pasien merasa puas dan patut untuk dipertahankan.

3. Kuadran III

Dalam kuadran ini di ditunjukan perihal pelayanan yang masih dianggap kurang penting bagi pasien tetapi jika dilihat dari tingkat kepuasan pasien kurang baik. Item yang termasuk dalam kuadran ini adalah tempat pelyanan dan pemberian informasi obat yang memadai; pelayan resep mudah dan tidak berbelit-belit; penyerhan obat selalu sesuai nomor antrian; petugas apotek segera menyiapkn obat ketika menerima resep; petugas apotek memberikan pelayana yang sama tanpa membedabedakan pasien. Walaupun dianggap kurang penting oleh pasien namun pelaksanaannya relatif rendah sehingga bila proritas utama sudah selesai diperbaiki maka proritas rendah ini dapat dilakukan.

4. Kuadran IV

Ditunjukkan perihal yang dinilai berlebihan oleh pasien, disebabkan pasien menganggap pelayanan tersebut tidak terlalu penting. Tetapi pelaksanaannya telah dilakukan dengan baik. Itemitem yang termasuk dalam kuadran ini adalah kerapian dan kebersihan ruang tunggu; kerapian penampilan petugas apotek; obat yang diresepkan selalu tersedia di apotek; petugas apotek tanggap masalah pasien; tempat penyerahn obat yang memadai; obat yag diserahkan kepada pasien dalam kondisi baik.

\section{Uji Normalitas Data}

Tabel 2. Uji Normalitas Data

\begin{tabular}{|l|l|l|}
\hline & Sig. & Kesimpulan \\
\hline Puskesmas Puuwatu & 0,20 & Data terdistribusi normal \\
\hline
\end{tabular}

Pengujian normalitas data dilakukan menggunakan uji kolmogrov-somirnov karena jumlah sampel besar (lebih dari 50 responden). Hasil analisis menghasilkan nilai 
signifikasi > 0,05 maka data dapat terdistribusi normal dan dapat dilanjutkan dengan uji paire t test.

\section{E. Uji T Berpasangan}

Tabel 3. Uji T Berpasangan

\begin{tabular}{|l|c|c|}
\hline & Sig. & Mean \\
\hline Puskesmas Puuwatu & 0,000 & 0,27 \\
\hline
\end{tabular}

Uji T berpasangan adalah analisis dengan melibatkan dua pengukuran pada subjek yang terhadap suatu pengaruh. Berdasarkan Hasil yang terdapat pada uji T nilai mean pada Puskesmas Puuwatu memiliki nilai mean 0,27 hal ini dapat diartikan kepuasan yang didapatkan oleh pasien lebih dari harapan yang diinginkan sehingga pasien sudah merasa puas kecuali pada tempat pelayanan dan pemberian informasi obat karena pasien menginginkan tempat pemberian informasi obat terpisah dengan tempat penyerahan obat, kenyamanan dan kebersihan ruang tunggu hal ini karena ruang tunggu dari apotek puskesmas ini terdapat diluar sehingga pasien merasa kurang nyaman; pelayanan resep yang mudah dan penyerahan obat sesuai nomor antrian pasien masih merasa kurang puas; petugas apotek tidak segera menyiapkan obat saat resep masuk sehingga waktu tunggu pasien makin lama dan pasien merasa kurang puas.

Berdasarkan tabel 4.10 diketahui bahwa berdasarkan perhitungan statistik uji T berpasangan didapatkan hasil ada perbedaan rata-rata penilaian responden dalam menilai kualitas pelayan dengan niali signifikan 0,000 .

\section{KESIMPULAN}

Berdasarkan perhitungan statistik uji $\mathrm{T}$ berpasangan didapatkan hasil ada perbedaan rata-rata penilaian responden dalam menilai kualitas pelayan dengan niali signifikan 0,000. Berdasarkan perhitungan statistik dangan uji $t$ ini diperoleh juga hasil bahwa ada kesenjangan (gap) antara layanan yang diharapkan dan layanan yang diberikan oleh apotek di Puskesmas Puuwatu Kota Kendari kepada pasien rawat jalan.

\section{UCAPAN TERIMA KASIH}

Terima kasih kepada Fakultas Farmasi Universitas Halu Oleo, Dinas Kesehatan Kota Kendari, Puskesmas Puuwatu dan Ikatan Apoteker Indonesia Pengurus Cabang Kota Kendari.

\section{REFERENSI}

I. Barlow \& Janelle. 20 I0. Branded Customer Service. New York: The New Competitive Edge.

2. Adiasmito, W. 2010. Sistem Kesehatan.Jakarta: PT. Grafindo Persadam.

3. Kementerian Kesehatan RI, Permenkes No. 74 Tahun 2016.Tentang Standar Pelayanan Kefarmasian di Puskesmas.Jakarta: Kementrian Kesehatan.

4. Supriyanto \& Ernawaty. 20I0. Pemasaran Industri Jasa Kesehatan. Yogyakarta: Andi Offset.

5. Radito, T.H. 20I4. Analisis Pengaruh Kualitas Pelayanan dan Fasilitas Kesehatan Terhadap Kepuasan Pasien Puskesmas. Jurnal Ilmu Manajemen. I I (2): I-26.

6. Tjiptono, T. \& Chandra G. 20II. Service, Quality and Satisfaction $3^{\text {rd }}$. Yogyakarta: Andi Offset.

7. Tanan. L, Indar \& Darmawansyah. 20I3. Analisis Tingkat Kepuasan Pasien di Puskesmas Bara Permai Kota Palopo. Jurnal AKK. 2(3): I5-2I.

8. Supranto. 2006. Mengatur Tingkat Kepasan Pelanggan atau Pasien.Jakarta: Rineka Cipta.

9. Assuari, S. 201 3.Costomer Service yang Baik Landasan Pencapaian Customer dalam Usahawan. Jakarta.

10. Mawarti, F. Fauziah, N.K. \& Husni, T. 2016. Analisis Kualitas Pelayanan Puskesmas Terhadap Kepuasan Ibu Hamil di Kota Pangkal Pinang Tahun 20 I5. Jurnal Kedoteran dan Kesehatan, 3(I) : 362-37I.

II. Sastroasmoro, S. \& Ismael, S. 20II.Dasar-dasar Metodologi Penelitian Klinis. Jakarta: Binarupa Aksara.

12. Parasuraman, A. Zeithaml \& Berry. 2004. Servqual: Multiple-Item Scale for Measuring Consumer Percceptions of Service Quality, Journal of Retaling.Vol 64. 